precise moment of extubation to avoid a true open pneumothorax in an extubated patient. We currently test all recipients of undersized lungs and avoid the combination of pleural suction and positive-pressure ventilation if patients demonstrate any evidence of breath stacking.

\section{References}

1. Sharp JT, Hammond MD. Pressure-volume relationships. In: Crystal RG, West JB, editors. The lung: scientific foundations. 1st ed. New York: Raven Press; 1991. p. 839-54.

2. Hosenpud JD, Bennett LE, Keck BM, Boucek MM, Novick RJ. The
Registry of the International Society for Heart and Lung Transplantation: eighteenth-official report-2001. J Heart Lung Transplant. 2001;20:805-15.

3. Timby J, Reed C, Zeilender S, Glauser FL. Mechanical causes of pulmonary edema. Chest. 1990;98:973-9.

4. Haniuda M, Hasegawa S, Shiraishi T, Dresler CM, Cooper JD, Patterson GA. Effects of inflation volume during lung preservation on pulmonary capillary permeability. J Thorac Cardiovasc Surg. 1996; 112:85-93.

5. Waller DA, Keavey P, Woodfine L, Dark JH. Pulmonary endothelial permeability after major lung resection. Ann Thorac Surg. 1996;61: 1435-40.

6. Shapira OM, Shahian DM. Postpneumonectomy pulmonary edema. Ann Thorac Surg. 1993;56:190-5.

\title{
Resection of anterior mediastinal tumor through a ministernotomy: Preliminary experience with ten cases
}

\author{
Philippe Icard, MD, Olivier Le Page, MD, Massimo Massetti, MD, Barbara Alkofer, MD, Jean Philippe Le Rochais, MD, \\ and André Khayat, MD, Caen, France
}

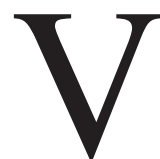

arious minimally invasive surgical approaches have recently been proposed for the management of valvular heart disease $\mathrm{e}^{1,2}$ and of myasthenia gravis related to thymic hyperplasia. ${ }^{3,4}$ In this report we review our preliminary experience of anterior mediastinal tumor resection through a ministernotomy.

\section{Patients}

Since October 2000, a total of 10 patients (6 men and 4 women, mean age 5 years, range 19-73 years) underwent surgical resection through a ministernotomy of a suspected anterior mediastinal tumor or mass measuring less than $7 \mathrm{~cm}$ on computed tomographic (CT) scan. The characteristics of all patients and tumor findings are presented in Table 1.

\section{Surgical Technique}

The opening technique was the same as that for aortic and mitral valve operation, a technique that has been previously described in our department by Massetti and colleagues. ${ }^{2}$ In brief, a midline skin incision (6-7 cm long) was made according to the location of

\footnotetext{
From the Departments of Thoracic and Cardio-Vascular Surgery CHRU de Caen, Caen, France.

Received for publication May 28, 2002; accepted for publication June 13, 2002.

Address for reprints: Philippe Icard, MD, Department of Thoracic and Cardio-Vascular Surgery, CHRU de Caen, 14033 Caen Cedex, France (E-mail: icard-p@chu-caen.fr).

J Thorac Cardiovasc Surg 2003;125:432-4

Copyright $\odot 2003$ by The American Association for Thoracic Surgery

$0022-5223 / 2003 \$ 30.00+0$

doi: $10.1067 / \mathrm{mtc} .2003 .136$
}

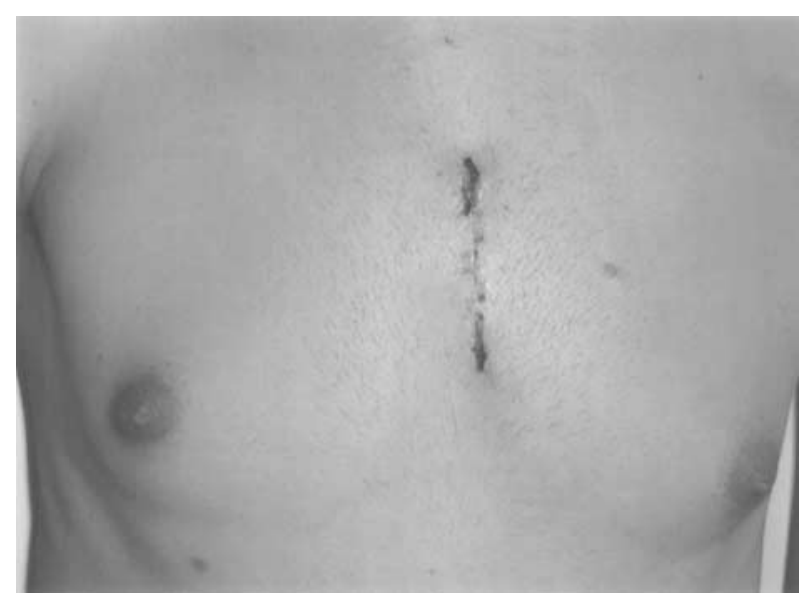

Figure 1. Skin incision of patient 9 on fourth postoperative day.

the lesion or tumor visible on CT scan, generally going from the second to the fourth interspace or from the third to the fifth interspace. In all cases the incision was clearly less than half of the length of the sternal bone. The skin and subcutaneous tissue were dissected, and a median sternotomy (manubrium and body) was carried out with a sagittal saw (Zimmer Micro 100; Linvatee, Largo, Fla); the portion of the sternum under the skin flap (cephalad and caudal) was easily divided with the aid of an illuminating disposable retractor (USSC Mini Harvest; United States Surgical Corporation, Norwalk, Conn). Once the thoracic retractor (such as a Tuffier device) was inserted, the spreading of the two sternal edges was limited to 5 to $6 \mathrm{~cm}$. The section of the sternal bone ended at the xiphoid appendage, which was preserved. According to Port and Ginsberg, 5 all surgical principles for resection of mediastinal tumors were strictly respected; that is, en bloc resec- 
TABLE 1. Patient characteristics

\begin{tabular}{|c|c|c|c|c|c|c|c|}
\hline Patient & $\begin{array}{l}\text { Age } \\
\text { (y) }\end{array}$ & Sex & Indication and pathologic findings & Tumor size (cm) & Tumor weight $(\mathbf{g})$ & $\begin{array}{l}\text { Hospital } \\
\text { stay (d) }\end{array}$ & $\begin{array}{c}\text { Complementary } \\
\text { treatment }\end{array}$ \\
\hline 1 & 73 & $\mathrm{~F}$ & Myasthenia gravis with stage II thymoma & 7 & 46 & 6 & Radiation therapy \\
\hline 2 & 38 & $\mathrm{~F}$ & Mediastinal mass, stage II thymoma & 6 & 61 & 6 & Radiation therapy \\
\hline 3 & 55 & M & Mediastinal mass, benign teratoma & 3 & Not measurable & 5 & None \\
\hline 4 & 23 & M & $\begin{array}{l}\text { Residual tissue after chemotherapy for } \\
\text { seminoma, fibrosis }\end{array}$ & Not measurable & Not measurable & 5 & None \\
\hline 5 & 54 & M & Mediastinal mass, stage II thymoma & 7 & 62 & 6 & Radiation therapy \\
\hline 6 & 56 & M & $\begin{array}{l}\text { Mediastinal mass, thymic hyperplasia } \\
\text { with seminoma }\end{array}$ & 3 & 34 & 6 & Radiation therapy \\
\hline 7 & 29 & M & $\begin{array}{l}\text { Suspicion of thymoma on CT scan, } \\
\text { thymic hyperplasia }\end{array}$ & 4.5 & 48 & 6 & None \\
\hline 8 & 19 & $\mathrm{~F}$ & $\begin{array}{l}\text { Myasthenia gravis, suspicion of thymoma } \\
\text { on CT scan, thymic hyperplasia }\end{array}$ & Not measurable & 45 & 4 & None \\
\hline 9 & 27 & M & $\begin{array}{l}\text { Cushing syndrome with suspicion of } \\
\text { carcinoid tumor secreting } \\
\text { adrenocorticotropin, thymic } \\
\text { hyperplasia }\end{array}$ & 3 & 25 & 4 & None \\
\hline 10 & 34 & $\mathrm{~F}$ & Mediastinal mass, thymoma & 5 & 55 & 5 & None \\
\hline
\end{tabular}

tion with extracapsular dissection avoiding intrapleural dissection of any tumors (especially stage I and II thymomas) to prevent pleural spreading, and complete thymectomy including the upper cervical poles of the gland. Special care was taken to respect the phrenic nerves. In case of an overly large or invasive tumor that might require en bloc resection of pleura, pericardium, lung, innominate vein, or superior vena cava, conversion of the ministernotomy to a standard sternotomy could be easily and immediately performed. One or two mediastinal drains were left in place. We used Redon drainage (B. Braun, Melsungen, Germany) each time the pleura or the pericardium was left intact.

\section{Results}

Complete resection was achieved in all cases, without any difficulties. All patients were extubated immediately after surgery. None received blood transfusions. Mediastinal drains were removed on postoperative day 2 or 3 . Postoperative recovery of patients was fast, and all patients were able to walk on the medical unit starting from postoperative day 2 or 3 . All were discharged between postoperative days 4 and 6 , at which time they returned to their homes (Figure 1).

\section{Comment}

Our series demonstrates that a less invasive approach of anterior mediastinal tumors and diseases is possible in many cases when preoperative imaging does not show a large, extended, or invasive tumor. Recently Shimokawa and colleagues ${ }^{6}$ also recommended a limited skin incision approach to resect noninvasive thymomas. In their case report, Shimokawa and colleagues ${ }^{6}$ used an upper part sternotomy with hemitransection of the sternum to resect a stage II thymoma in a 71-year-old patient. We also think that every time the tumor or the mediastinal lesion does not seem too large and is clearly limited on preoperative CT scan (the reasonable limit is probably around $8 \mathrm{~cm}$ in diameter), complete surgical resection can be attempted through a modified median sternotomy, reducing the size of the skin incision. In case of technical difficulties or when the lesion appears too large or invasive to be removed safely through this small incision, conversion to standard median sternotomy can be performed immediately and easily. No modifications from the standard surgical technique are necessary except for the need for a good light, such as the one provided by the illuminating disposable retractor that we used. A special sternal bone retractor, such as those used for cardiac valve replacement, may also be helpful. ${ }^{2}$ A standard retractor such as the Tuffier seems sufficient to expose the anterior mediastinal space.

Complete excision of the tumor by an extracapsular dissection with strict avoidance of intrapleural dissection is strictly mandatory for resecting mediastinal tumors (such as stage I and II thymomas) and for preventing pleural spread. A videothoracoscopic approach has recently been proposed for resection of thymic hyperplasia in myasthenia gravis..$^{3,4}$ However, every time a tumor is suspected on the basis of a preoperative CT scan, we think that this video-assisted surgical technique should not be used to avoid the risk of any pleural spread. The cosmetic and psychologic advantages of ministernotomy are obvious and are of particular interest to young patients ( 6 of 10 patients in our series were $<35$ years old) and in female patients (Table 1). We intend to compare in a prospective study standard thoracotomy and ministernotomy for postoperative pain and duration of hospitalization, because these two variables appeared at first sight to be improved after this modified sternotomy. Postoperative discomfort of patients seemed to be reduced, maybe because of the narrower spreading of the two sternal edges that reduces the stretch on all thoracic ligaments and diaphragm attachments. The mean hospitalization was 5 days, rather than the 10 days seen after standard sternotomy in our department. Even if a randomized study does not demonstrate any physical or economic advantages of a reduced sternal skin incision, however, the esthetic and psychologic benefits argue for this approach every time it is possible. 


\section{References}

1. Hart RS. Minimally invasive heart surgery. Circulation. 1996;94: 2669-70.

2. Massetti M, Babatasi G, Lotti A, Bhoyroo S, Le Page O, Khayat A. Less invasive cardiac operations through median sternotomy: 100 consecutive cases. Ann Thorac Surg. 1998;66:1050-4.

3. Novellino L, Longoni M, Spinelli L, Andretta M, Cozzi M, Faillace G, et al. "Extended" thymectomy, without sternotomy, performed by cervicotomy and thoracoscopic technique in the treatment of myasthenia gravis. Int Surg. 1994;79:378-81.

4. Mack MJ. Video-assisted thoracoscopy for myasthenia gravis: surgery for thymoma. Chest Surg Clin North Am. 2001;11:389-405.

5. Port JL, Ginsberg RJ. Surgery for thymoma. Chest Surg Clin North Am. 2001;11:421-37.

6. Shimokawa S, Watanabe S, Sakasegawa I, Tani A. Ruptured thymoma causing mediastinal hemorrhage resected via partial sternotomy. Ann Thorac Surg. 2001;71:370-2.

\title{
Aggressive multimodality treatment of invasive thymic carcinoma
}

\author{
Michael A. Greene, MD, FCCP, and Mark A. Malias, MD, FCCP, \\ Melbourne, Fla
}

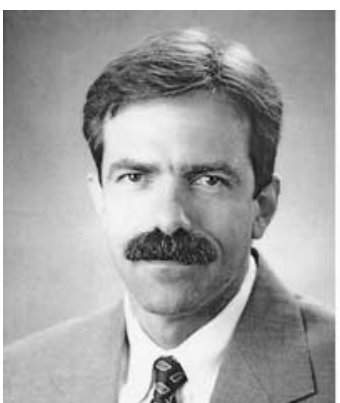

Greene

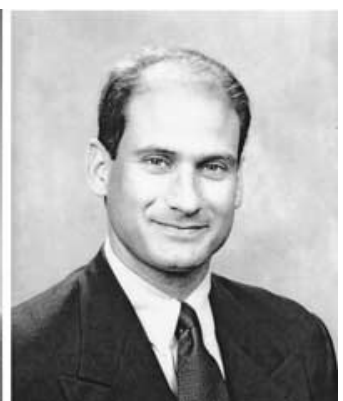

Malias
T hymic carcinomas are epithelial neoplasms of the thymus generally characterized by extensive local invasion and distant metastases. Overall prognosis is poor, with 5-year survivals of $31 \%$ to $50 \% .{ }^{1}$ Blumberg and associates $^{2}$ found innominate vessel invasion (vein or artery) to be the only statistically significant predictor of poor survival according to univariate analysis. We report a case of thymic carcinoma with extensive local invasion treated with en bloc surgical resection followed by chemotherapy and radiation.

\section{Clinical Summary}

A 48-year-old nonsmoking woman had an approximately 2-year history of intermittent chest discomfort attributed to costochondritis. After a day of vigorous physical exertion, she had acute shortness of breath and right-sided chest pain. She was treated with anti-inflammatory medications. However, a chest radiograph showed a prominent right hilum. She underwent chest computed tomographic and magnetic resonance imaging scans, which dem-

From Department of Surgery, University of Florida, Melbourne, Fla.

Received for publication May 29, 2002; accepted for publication July 15, 2002.

Address for reprints: Michael A. Greene, MD, FCCP, Health First Heart Institute, 1355 S. Hickory Street, Suite 202, Melbourne, FL 32901 (E-mail: mgreene@ health-first.org).

J Thorac Cardiovasc Surg 2003;125:434-6

Copyright $\odot 2003$ by The American Association for Thoracic Surgery

$0022-5223 / 2003 \$ 30.00+0$

doi: $10.1067 / \mathrm{mtc} .2003 .133$ onstrated a large $(8.5 \mathrm{~cm})$ anterior mediastinal mass (Figures 1 and 2). A biopsy specimen of the mass was obtained through a small anterior right parasternal incision, and moderately differentiated squamous cell thymic carcinoma was diagnosed (Figure 3).

The patient's en bloc surgical resection was extensive because of direct tumor invasion of the surrounding structures. Obtaining negative margins required resection of the right anterior chest wall with partial sternectomy, partial right lung upper lobectomy, and mediastinal soft tissue resection, including resection of the pleura, pericardium, and right phrenic nerve. Resection of tumor involvement of the innominate vein and superior vena cava was accomplished with systemic heparinization and the placement of a temporary shunt connecting the confluence of the right subclavian and jugular veins with the right atrium.

The superior vena cava was reconstructed with autologous pericardium. Transient sinus node dysfunction as a result of clamp occlusion of the superior vena caval-right atrial junction was treated during the operation with temporary atrial pacing.

The chest wall soft tissue defect was closed with a pectoralis rotational flap and local fasciocutaneous flap advancement. The patient was extubated after 3 days, with minimal paradoxic right chest wall excursion noted. An elevated right diaphragm as a result of phrenic nerve resection was observed, as expected, on the postoperative chest radiograph.

Oral anticoagulation therapy was started to prevent thrombosis of the extensive pericardial reconstruction of the innominate and superior caval veins. The patient was discharged after 11 days and later returned for outpatient placement of a femoral vein chemotherapy infusion port.

Subsequent treatment included chemotherapy consisting of 6 cycles of paclitaxel at $150 \mathrm{mg} / \mathrm{m}^{2}(255 \mathrm{mg})$ with 6 cycles of carboplatin (540 $\mathrm{mg}$ each dose), followed by radiation therapy (Table 1). Preoperative induction radiation of the tumor was 